\title{
Prediction of diesel engine performance, emissions and cylinder pressure obtained using Bioethanol-biodiesel- diesel fuel blends through an artificial neural network
}

\author{
Hasan Aydogan \\ Mechanical Engineering Department, Technology Faculty, Selcuk University, Konya, Turkey
}

\begin{abstract}
The changes in the performance, emission and combustion characteristics of bioethanol-safflower biodiesel and diesel fuel blends used in a common rail diesel engine were investigated in this experimental study. E20B20D60 (20\% bioethanol, 20\% biodiesel, $60 \%$ diesel fuel by volume), E30B20D50, E50B20D30 and diesel fuel (D) were used as fuel. Engine power, torque, brake specific fuel consumption, NOx and cylinder inner pressure values were measured during the experiment. With the help of the obtained experimental data, an artificial neural network was created in MATLAB 2013a software by using back-propagation algorithm. Using the experimental data, predictions were made in the created artificial neural network. As a result of the study, the correlation coefficient was found as 0.98 . In conclusion, it was seen that artificial neural networks approach could be used for predicting performance and emission values in internal combustion engines.
\end{abstract}

Keywords: artificial neural networks, diesel engine, biodiesel fuel, bioethanol

\section{Introduction}

Today, diesel engines are widely used in transportation, industry and agricultural areas because of their high fuel efficiency and ease of operation (Demirbas, 2008). The demand for diesel engines has been continuing to increase worldwide as a result of expanding industrialization ( $\mathrm{Ma}$ et al., 2013). This is because diesel engines have certain advantages compared to spark ignition engines such as low fuel consumption, high engine torque and longevity (Park and Lee 2013).

The limited nature of oil resources has made the studies on alternative energy sources much more important in diesel engines, in which oil products are used as an energy source (Canakci et al., 2006; Hazar, 2010; Hulwan and Joshi, 2011; Breda,
2011; Kannan et al., 2011; Fahd et al., 2013). The use of renewable energy sources in internal combustion engines may also contribute to decreasing the increase in air pollution (Ghobadian et al., 2009). Bioethanol and biodiesel are renewable energy sources (Mrad et al., 2012).

Bioethanol is obtained through the fermentation of agricultural products containing sugar and starch such as sugar beet, sugar cane, corn, wheat and wood-like plants (Park et al., 2012; Guido et al., 2013). The use of bioethanol in diesel engines provides a decrease in the amount of particulate matter (PM) in exhaust emissions (Zhou et al., 2013; Hadi et al., 2009; Yilmaz and Sanchez, 2012). The decrease in PM (smoke) is related to the amount of oxygen contained in fuel blends (Shi et al., 2005).

Biodiesel is a product which comes from the reaction of oils obtained from oilseed plants like canola, sunflower, soybean and safflower or from animal fats with a short-chain alcohol (methanol or ethanol) in the presence of a catalyst and can be used as fuel (Brunschwig et al., 2012; Acaroglu and Aydogan 2012). The biggest advantage of the use of biodiesel fuel is that it can be used without performing any modifications on the engine (Torrisi and Sabino, 2013; Aydogan et al., 2011, Adeyemo et al., 2011).

Conducting performance experiments on engines using different operating conditions and different fuels requires cost and time. At this point, artificial neural networks (ANN) can be used in order to decrease costs and save time (Ghazikhani and Mirzaii, 2011). Different variables can be predicted by using the data obtained in previously conducted experiments. In recent years, the applicability of an artificial neural network method for internal combustion engines has gained considerable success (Sharkey et al., 2000; Yilmaz and Bilgin 2013).

There are several studies conducted through the ANN approach. In a study, Uzun (2014) used the ANN approach to predict air mass flow in a diesel engine. Çay (2013) showed that ANN approach could be used for predicting performance values in 
a gasoline engine. In their study, Ghazikhani and Mirzaii (2011) stated that correct predictions at a rate of $99 \%$ could be made in predicting the soot emissions of a diesel engine by using the ANN approach. Ghobadian et al. (2009) used ANN for predicting engine performance and exhaust emissions with the use of biodiesel obtained from waste oils.

In the present study, biodiesel and bioethanol obtained from safflower oil and diesel fuel blends were used in an engine with a common rail fuel system. The use of the ANN approach was examined using the measured values.

\section{Experimental setup and procedure}

Low-sulphur diesel fuel (Euro diesel) was purchased for the tests. Bioethanol produced from sugar beet was obtained from Konya Seker Inc. Safflower oil was used for producing biodiesel. Safflower oil was processed into biodiesel through transesterification. Three different fuel blends were prepared by using these fuels. The ratios of the fuel blends used in the experiments were determined based on the suggestions provided in previous studies. Density, kinematic viscosity and lower heating value (LHV) of the prepared fuel blends were measured. Fuel blends and their properties are presented in Table 1. The fuel blends were prepared right before the experiments in order to ensure homogeneity. Furthermore, the fuel in the tank was mixed using a mixer in order to prevent phase separation.
A water-cooled, turbocharged diesel engine with an intercooler and a common rail fuel system was used in the study. The schematic diagram of the experimental setup used in the study is presented in Figure 1. All the experiments were conducted without performing any modifications on the engine. The technical specifications of the test engine are presented in Table 2. An AVL GH13P/AG04 cylinder pressure sensor and AVL 365C Crank angle encoder were installed on the test engine. Afterwards, the test engine was connected to a hydraulic dynamometer. Fuel consumption was measured by using a Dikomsan ${ }^{\mathrm{TM}}$ JS-B model electronic scale. A digital chronometer was used in order to determine the fuel consumption per unit time. An Orifice ${ }^{\mathrm{TM}}$ plate and differential pressure manometer was used to measure the air consumption of the engine. Exhaust temperatures were measured using a K-type thermocouple. A Bosch BEA 350 gas analyser and Bosch RTM 430 smoke meter were used to measure the exhaust emissions. The specifications of the exhaust measuring devices and the calculated uncertainty values are presented in Table 3. All the tests were conducted at full-throttle opening. Before starting the tests, the engine was operated until it reached a stable condition. Afterwards, the experiments were started. Engine speed, engine power, engine torque, fuel consumption and exhaust emission values were recorded during the experiment. During the measurement of the in-cylinder gas pressure, the pressure values

Table 1: Some properties of the test fuels

\begin{tabular}{lccccc}
\hline Fuel property & $D$ & E20B20D60 & E30B20D50 & E50B20D30 & $\begin{array}{c}\text { Measurement } \\
\text { method }\end{array}$ \\
\hline Bioethanol content (\%) & 0 & 20 & 30 & 50 & \\
\hline Biodiesel content $(\%)$ & 0 & 20 & 20 & 20 & \\
\hline Diesel Fuel content $(\%)$ & 100 & 60 & 50 & 30 & \\
\hline Density $\left(\mathrm{kg} / \mathrm{m}^{3}\right)$ at $15^{\circ} \mathrm{C}$ & 826.7 & 839.2 & 835.1 & 825.1 & ASTM D4052 \\
\hline Kinematic Viscosity $\left(\mathrm{mm}^{2} / \mathrm{s}\right)$ at $40^{\circ} \mathrm{C}$ & 2.8221 & 2.4645 & 2.4853 & 2.0139 & ASTM D445 \\
\hline Lower heating value $(\mathrm{Mj} / \mathrm{kg})$ & 47.521 & 39.322 & 38.966 & 34.131 & ASTM D240 \\
\hline
\end{tabular}

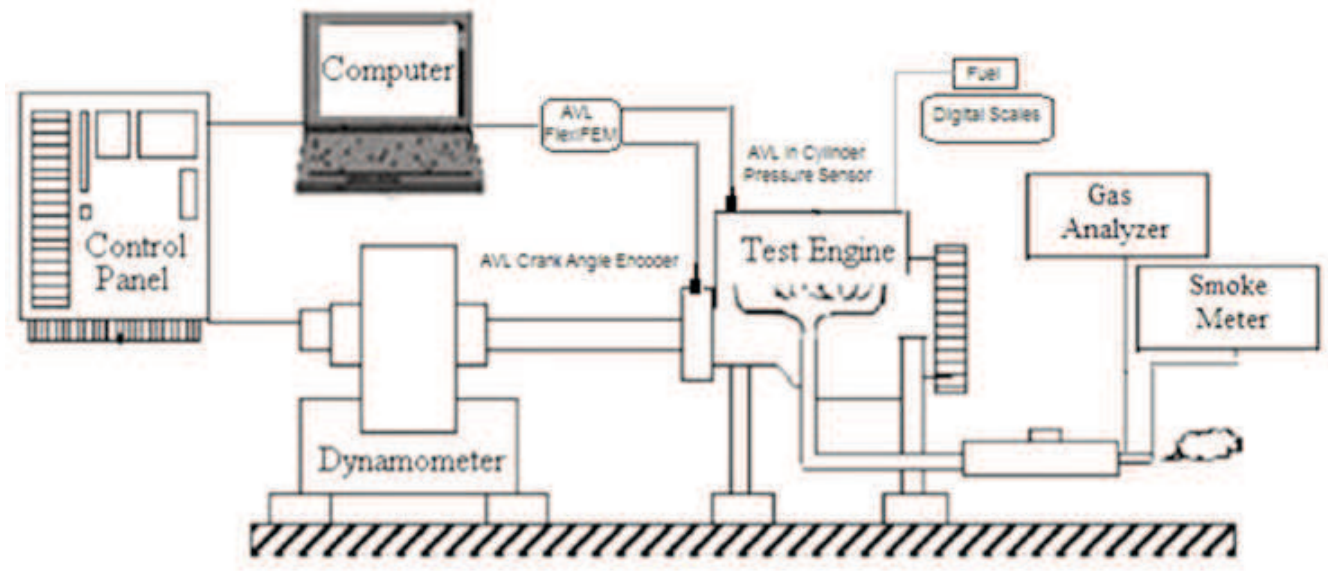

Figure 1: The schematic diagram of the experimental setup 
were recorded at each 0.5 degree of the crankshaft through 120 cycles and the mean values were calculated. The relative humidity, ambient temperature and pressure of the test room were measured using a hygrometer, a thermometer and a barometer, respectively. The fuel pump, fuel pipes and the fuel filter were emptied at each fuel change. All the experiments were repeated three times and the means of the obtained values were calculated.

Table 2: Specifications of the test engine

\begin{tabular}{ll}
\hline Engine type & $\begin{array}{l}\text { Water-cooled, four stroke, } \\
\text { turbo charged, intercooler, } \\
\text { common rail fuel system }\end{array}$ \\
\hline Number of cylinders & 4 \\
\hline Cylinder volume & $1910 \mathrm{~cm}^{3}$ \\
\hline Bore and stroke & $82 \times 90.4(\mathrm{~mm})$ \\
\hline Compression ratio & $18.5 / 1$ \\
\hline Maximum torque & $200 \mathrm{Nm} @ 1750 \mathrm{rpm}$ \\
\hline Maximum power & $77 \mathrm{~kW} @ 4000 \mathrm{rpm}$ \\
\hline Number of holes in nozzle & 4 \\
\hline Size of nozzle & $0.132 \mathrm{~mm}$ \\
\hline
\end{tabular}

\section{Experimental results}

The variation of engine power depending on engine speed is presented in Figure 2. As it can be seen in Figure 2, the power curves are similar in shape. As a result of the tests, it was seen that the highest engine power was obtained at $3000 \mathrm{rpm}$ with all types of fuels. At this engine speed, engine power was measured as $46.3 \mathrm{~kW}$ with the use of $\mathrm{D}$ fuel, $44 \mathrm{~kW}$ with the use of E20B20D60 and E30B20D50 fuels and $39.75 \mathrm{~kW}$ with the use of E50B20D30 fuel. Engine power showed a decrease as the percentage of the bioethanol in the fuel blends increased. The engine power obtained through the use of fuel blends was found to be approximately $15 \%$ lower compared to diesel fuel. The major reason for the decrease in engine power is the difference between the heating values of the fuels. As it can be seen in Table 1, LHV values of the fuels decreased as the ratio of bioethanol in the blend increased.

When we examine the engine torque values given in Figure 3, we can see that a similar curve was formed with all types of fuels. The highest torque values were observed at $2000 \mathrm{rpm}$. Engine torque values showed a decrease as the ratio of the bioethanol in the fuel blend increased. At 2000 $\mathrm{rpm}$, engine torque was measured as $185.59 \mathrm{Nm}$ with D fuel, $175 \mathrm{Nm}$ with E20B20D60 fuel, 170 $\mathrm{Nm}$ with E30B20D50 fuel and $153 \mathrm{Nm}$ with E50B20D30 fuel. When we look at the lowest value, it is seen that there was an approximately $18 \%$ decrease compared to D fuel.

The brake specific fuel consumption (BSFC) values presented in Figure 4 shows that the lowest value was obtained within the range of 2000-3000 $\mathrm{rpm}$. Engine torque and engine power also reached the highest values at this speed range. As shown in Figure 4, BSFC values increased as the ratio of bioethanol in the fuel blend increased. At 2500 $\mathrm{rpm}$, the lowest BSFC value was $225 \mathrm{~g} / \mathrm{kWh}$ with the use of $\mathrm{D}$ fuel, while the highest $\mathrm{BSFC}$ value was $267 \mathrm{~g} / \mathrm{kWh}$ with the use of E50B20D30 fuel. This value is $18 \%$ higher compared to the BSFC value obtained with the use of $\mathrm{D}$ fuel. The amount of fuel used by the engine shows an increase as the heating value of the fuel decreases (Stone 1999; Zhu et al., 2010; Armas et al., 2011, Soloiu et al., 2013).

The most important problem in diesel engines is the NOx emissions (Morisugi and Ohno 1996, Hsieh et al. 2002, Armas et al. 2011, Agarwal and Dhar 2013). The high temperatures reached during the combustion in the cylinder combines the oxygen with the nitrogen in the air to form NOx (SAE 2001). Humidity has a large inПuence on NOx emissions (Pilusa et al. 2013). Therefore, in this study, humidity in the air was continuously measured. The humidity correction factor for NOx was calculated as stated by the Society of Automotive Engineers (Qi et al., 2011). The variation of NOx emissions at different engine speeds is presented in Figurer 5. NOx concentration first showed an increase depending on engine speed. However, it started to decrease after reaching the maximum torque speed. Maximum NOx values were measured as $1488 \mathrm{ppm}$ with the use of E50B20D30 fuel at $2500 \mathrm{rpm}$. This value was approximately $32 \%$ higher compared to the value obtained with $\mathrm{D}$ fuel. Bioethanol contains 34\% oxygen 14. Furthermore, its low cetane number compared to that of diesel

Table 3: Technical details of the emissions measuring equipment

\begin{tabular}{llllll}
\hline Equipment & Method & Measurement & Upper limit & Accuracy & Uncertainty \\
\hline Bosch BEA 350 & Non-dispersive infrared & $\mathrm{CO}$ & $10.00 \mathrm{vol} . \%$ & $0.001 \mathrm{vol} \%$ & 0.002 vol.\% \\
\hline & Non-dispersive infrared & $\mathrm{CO}_{2}$ & $18.00 \mathrm{vol} \%$ & $0.001 \mathrm{vol} . \%$ & 0.150 vol.\% \\
\hline & Non-dispersive infrared & $\mathrm{HC}$ & $9999 \mathrm{ppm}$ vol. & $1 \mathrm{ppm}$ vol. & $2 \mathrm{ppm}$ vol. \\
\hline & Electro-chemical transmitter & $\mathrm{NO}$ & $5000 \mathrm{ppm}$ vol. & $1 \mathrm{ppm}$ vol. & $21 \mathrm{ppm}$ vol. \\
\hline Bosch RTM 430 & Photodiode receiver & Smoke opacity $100 \%$ & $0.1 \%$ & $0.8 \%$ \\
\hline
\end{tabular}




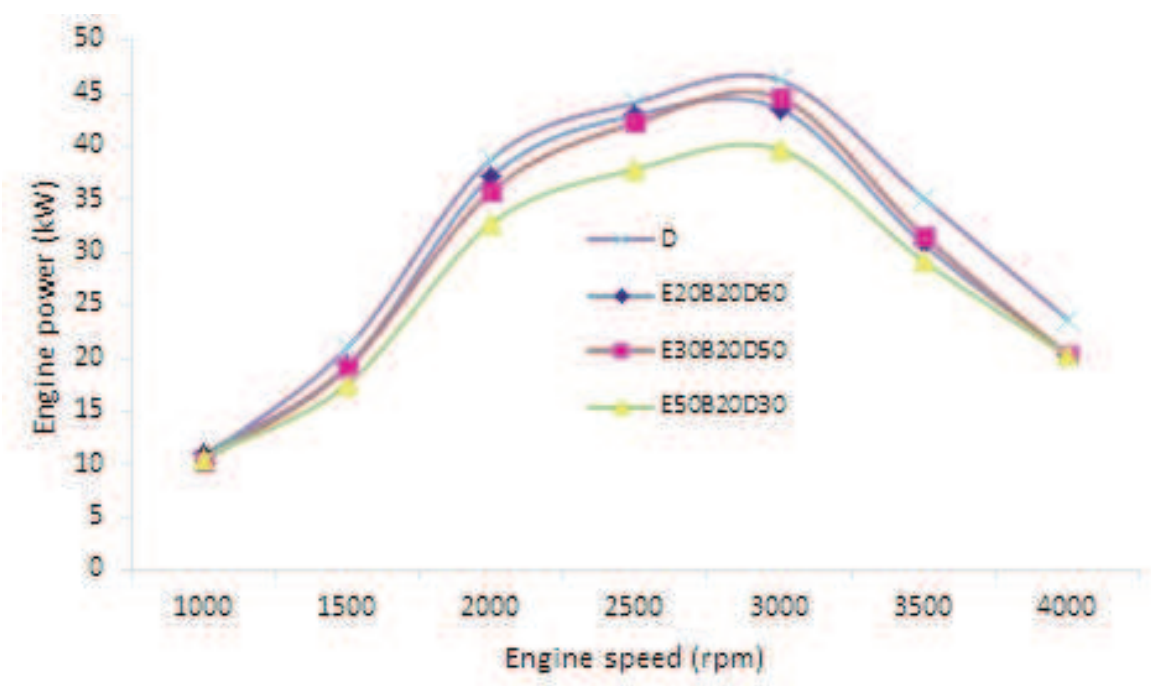

Figure 2: Variation of engine power depending on engine speed

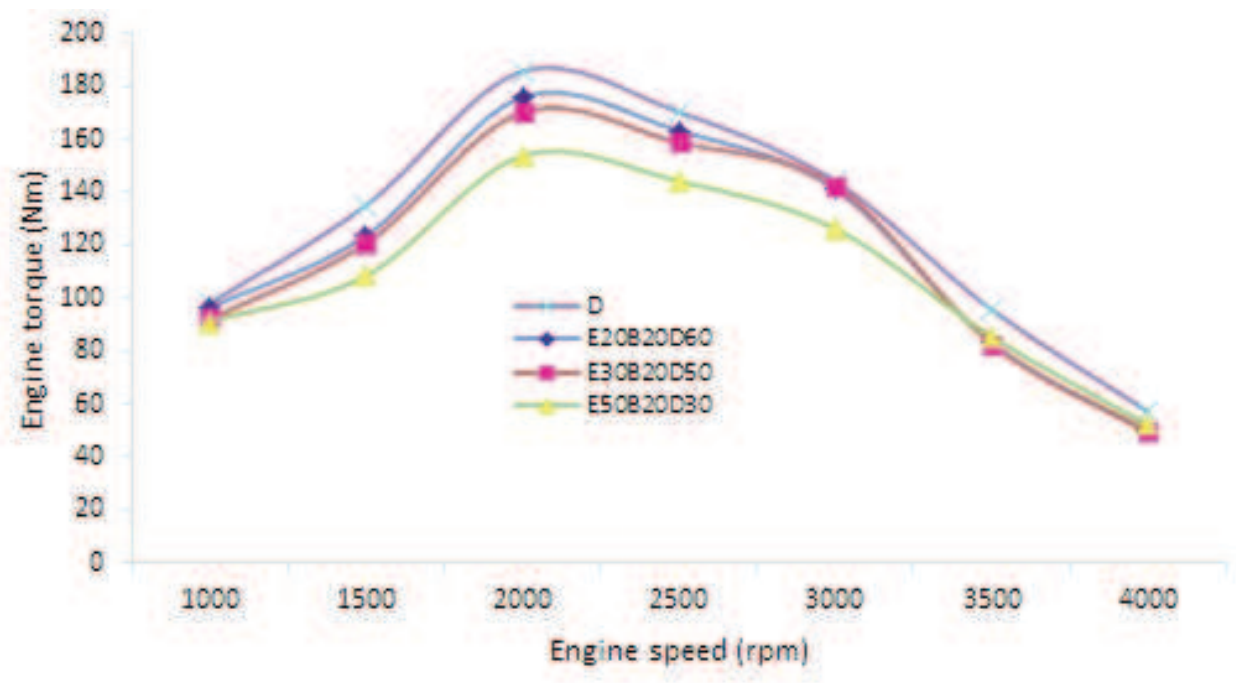

Figure 3: Variation of engine torque depending on engine speed

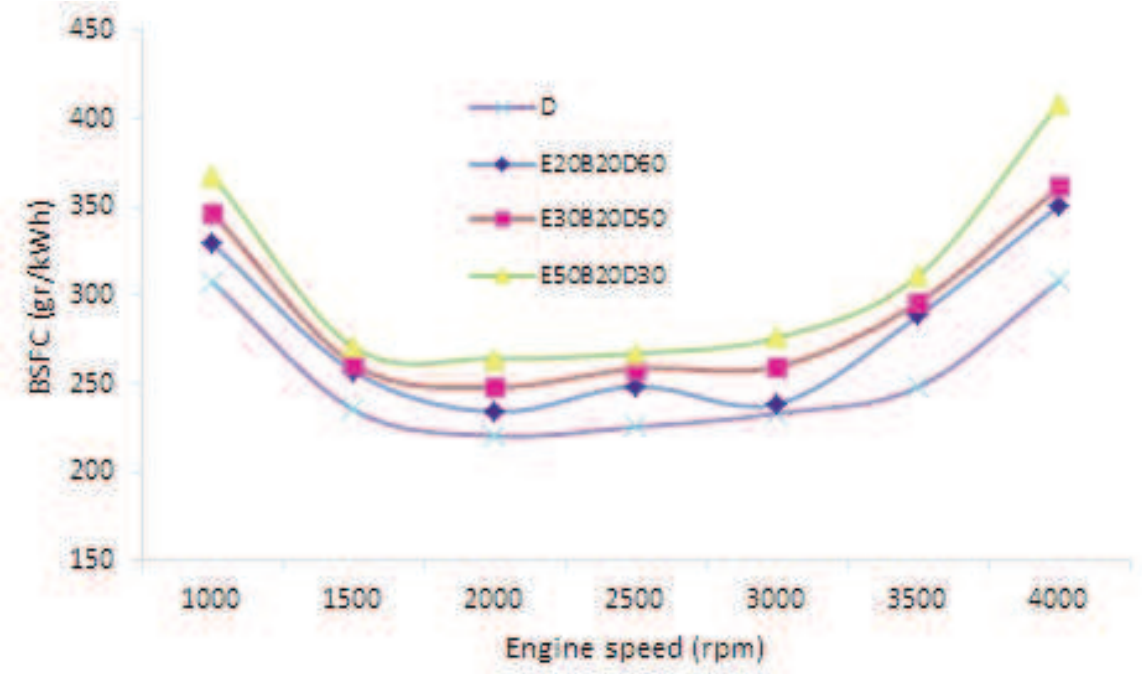

Figure 4: Variation of BSFC values depending on engine speed 


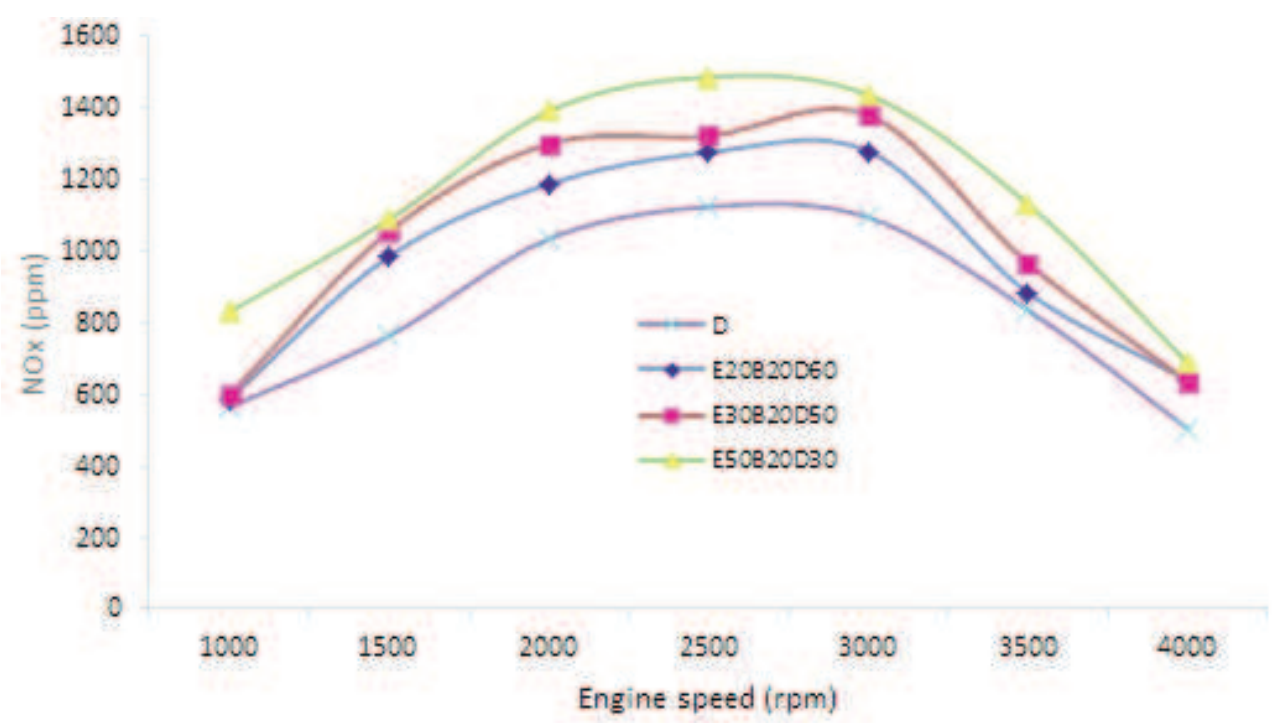

Figure 5: Variation of NOx values depending on engine speed

fuel increases the peak temperature in the cylinder (Amiri et al., 2011). For this reason, the concentration of NOx emissions increased with the use of all types of test fuels containing bioethanol.

\section{Artificial neural networks}

The concept of ANN is a calculation model which emerged as an inspiration of the working principle of the biological neural system. ANN is a method which has appeared as the result of the studies on modelling the learning ability of the neurons in the human brain and which has effective abilities for numerical optimization applications (Sefriti et al., 2002). ANN structure is generally composed of factors such as processing components, structural distribution of the neural network and learning rules. ANN is composed through the organization of processing components in totally or partly connected ordered layers (Ioanaş, 2002; Balti et al., 2013). These layers are composed of input, hidden and output layers and a desired number of processing components is used in each one (Figure 6). The processing components in the input layer receive the information from the outside world and deliver it to the middle layer (Hafaifa et al., 2013; Singh et al., 2013). In some networks, no information processing occurs in this layer. The middle layer, i.e. the hidden layer processes the information received from the input layer and transfers it to the output layer. There may be more than one middle layer in a network. The processing components in the output layer process the information received from the middle layer for the input set submitted from the input layer of the network (Uzun, 2014).

In the present study, an ANN model was developed by using the data obtained from the conducted experimental studies. Training sets were created by randomly selecting the $70 \%$ of the data obtained in the experimental study. The remaining $30 \%$ data was used for testing purposes. Firstly, a normalizing

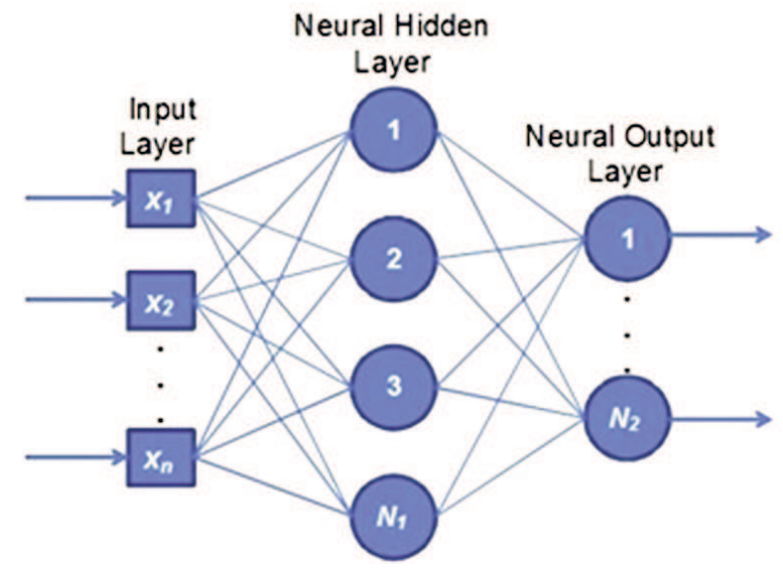

Figure 6: Artificial neural networks

process was conducted in order to enable the use of the data within the ANN structure. Thus, all the data obtained a value between $0-1$. The formula used for the normalizing process is presented below (Aydogan et al., 2011, Ismaila et al., 2012):

$$
X_{N}=0.8 x\left[\frac{X_{R}-X_{\min }}{X_{\max }-X_{\min }}\right]+0.1
$$

$X_{N}=$ normalized data

$X_{R}=$ data to be normalized

$X_{\min }=$ data with the smallest value

$X_{\max }=$ data with the biggest value

MATLAB 2013a software was used for the ANN study. Back propagation (BP) algorithm, Levenberg-Marquardt Back propagation (TRAINLM), Gradient descent with momentum and adaptive learning rate back propagation (TRAINGDX) training functions were used for the ANN structure. Logsig was preferred as the transfer function. The ANN structure used in the study is presented in Figure 7. One input layer, one hidden layer and one 
output layer were used in the ANN. While the engine speed and the fuel type of the test engine constituted the input values, torque, power, SFC, NOx and maximum cylinder inner pressure (Pmax) values constituted the output values. The performance of the ANN is directly affected by variables such as the number of the neurons in the hidden layer and the number of hidden layers. The configuration that yielded the best correlation coefficients were tried to be created by forming different ANN configurations. The number of the neurons in the hidden layer was selected as 6, 7, 8, 9, 10, 15, 20 and 50 and the ANN application was repeated. As the result of the study, it was found that the best correlation values were obtained through using TRAINLM training function, logsig transfer function and 20 neurons in the hidden layer (Table 1). The formula of the logsig transfer function is presented below. Mean squared error (MSE) was used for the performance index of the TrainLM algorithm and its formula is given below (Aydogan et al., 2011):

$$
\begin{aligned}
& \log \operatorname{sig}(\mathrm{n})=\left(\frac{1}{1+e^{-n}}\right) \\
& M S E=\frac{1}{n} \sum_{i=1}^{n}\left(y_{i}-y_{k}\right)^{2}
\end{aligned}
$$
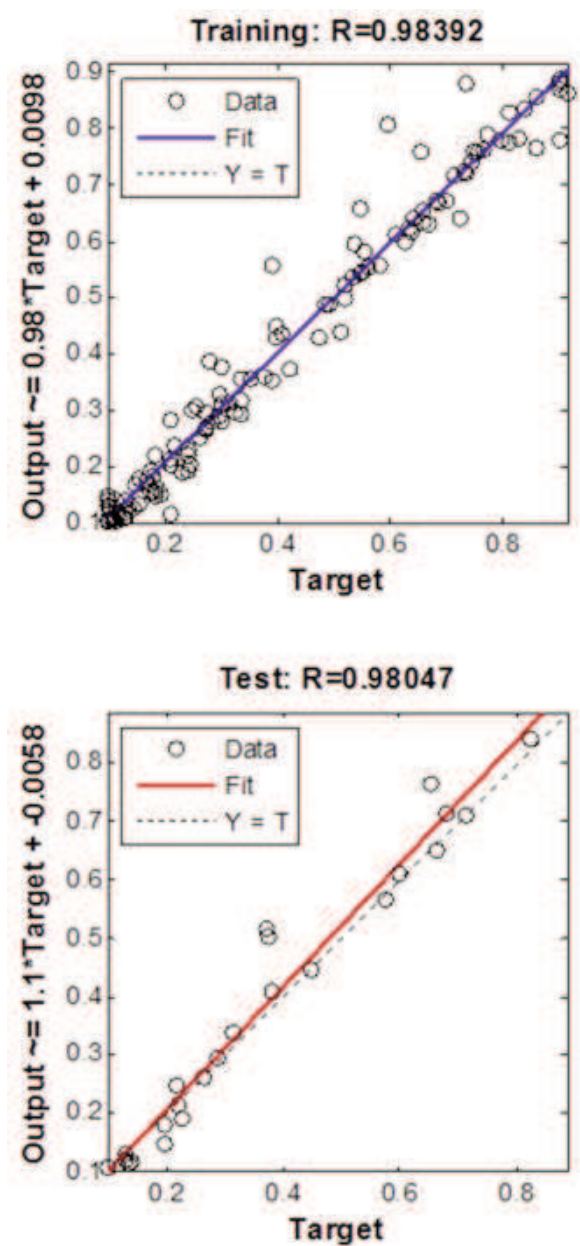

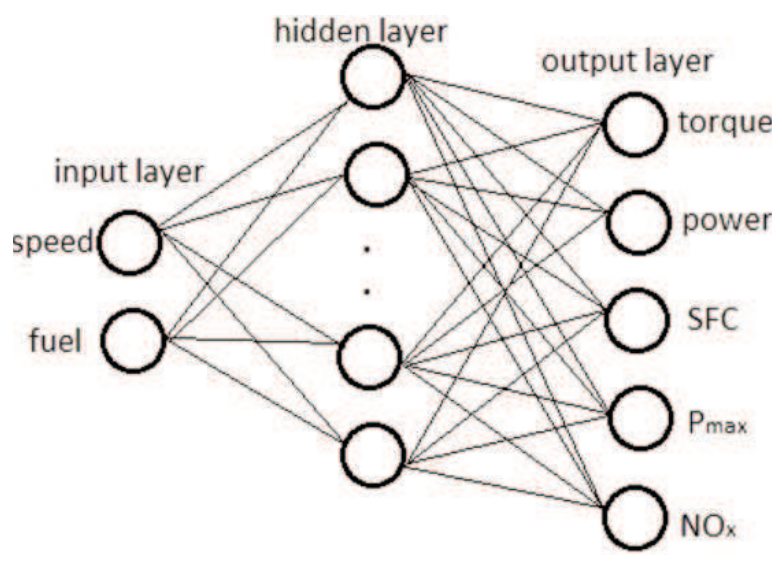

Figure 7: Architecture of the NN model

where, $y_{i}$ is predicted value of $i^{\text {th }}$ pattern, $y_{k}$ is the target value of the $\mathrm{i}^{\text {th }}$ pattern and $\mathrm{n}$ is the number of patterns. $\mathrm{R}$ values of training, validation and test data of the ANN created in the study are presented in Figure 8.

Engine power, engine torque, BSFC, NOx and Pmax values, both experimental and predicted through ANN, are graphically presented in Figure 9. When the Figure. is examined, it can be seen that the predicted values and experimental values are close to one another. The closeness of the values
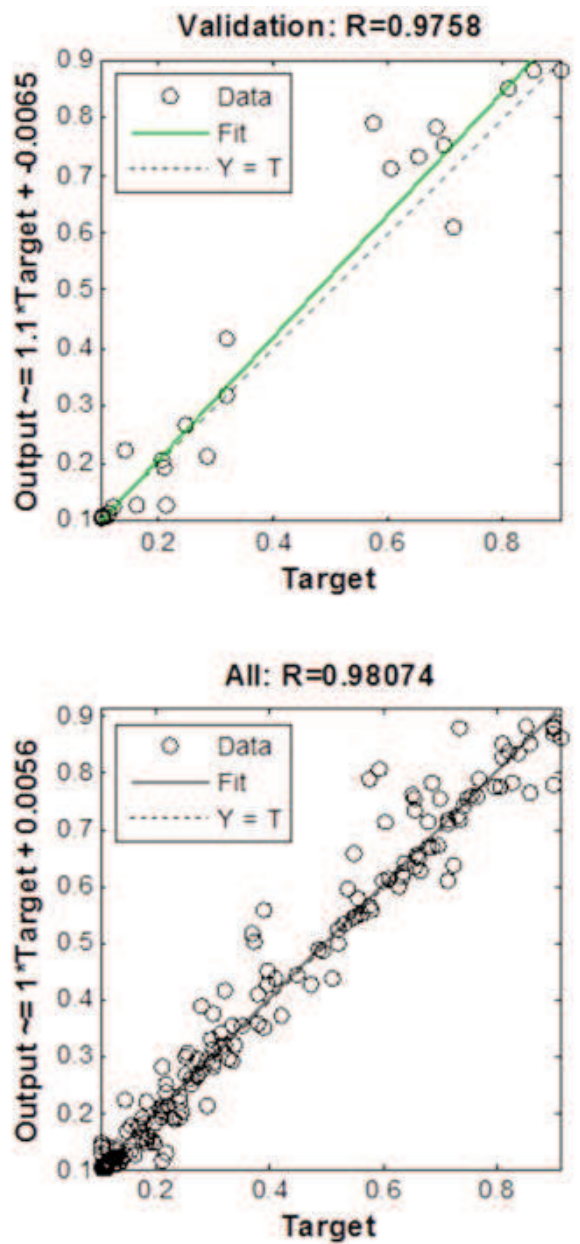

Figure 8: $\mathbf{R}$ values of training, validation and test data 


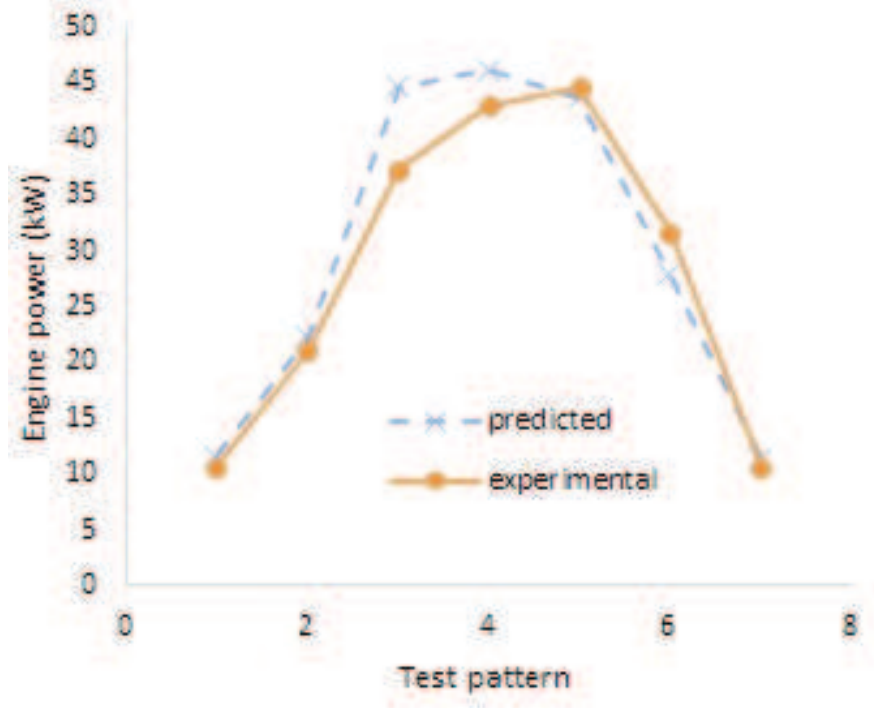

(a)

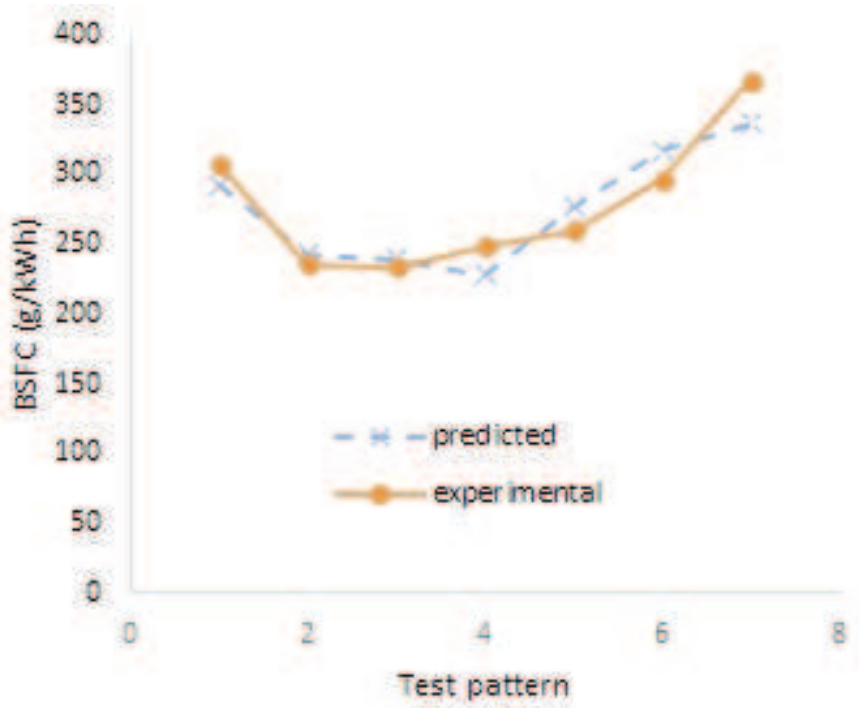

(c)

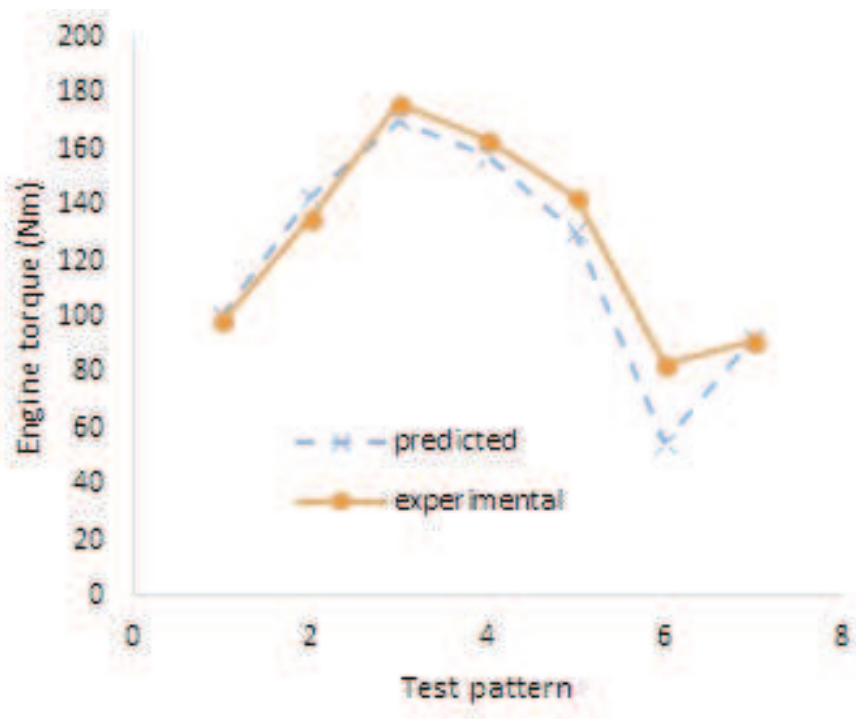

(b)

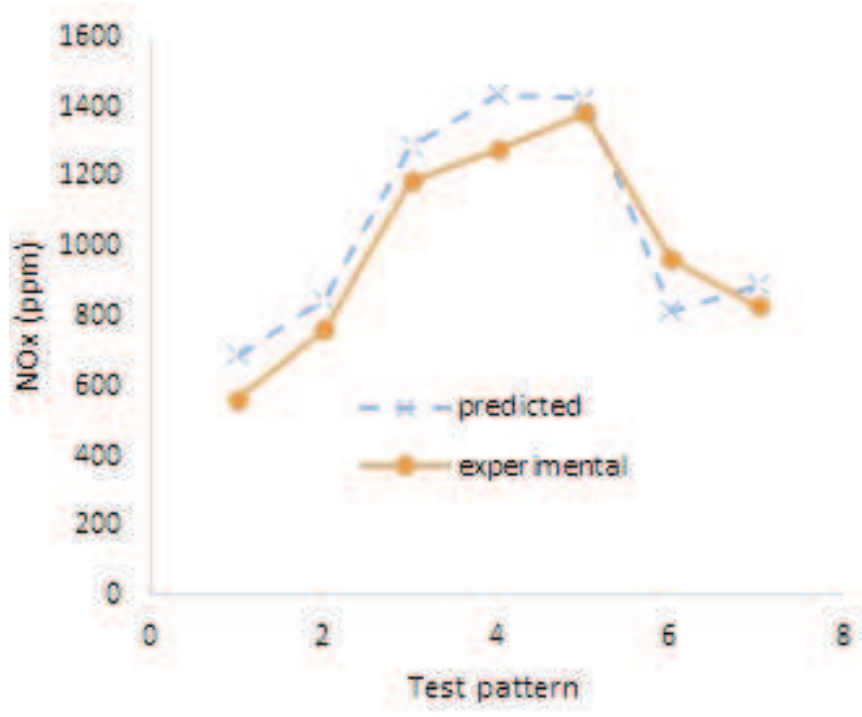

(d)

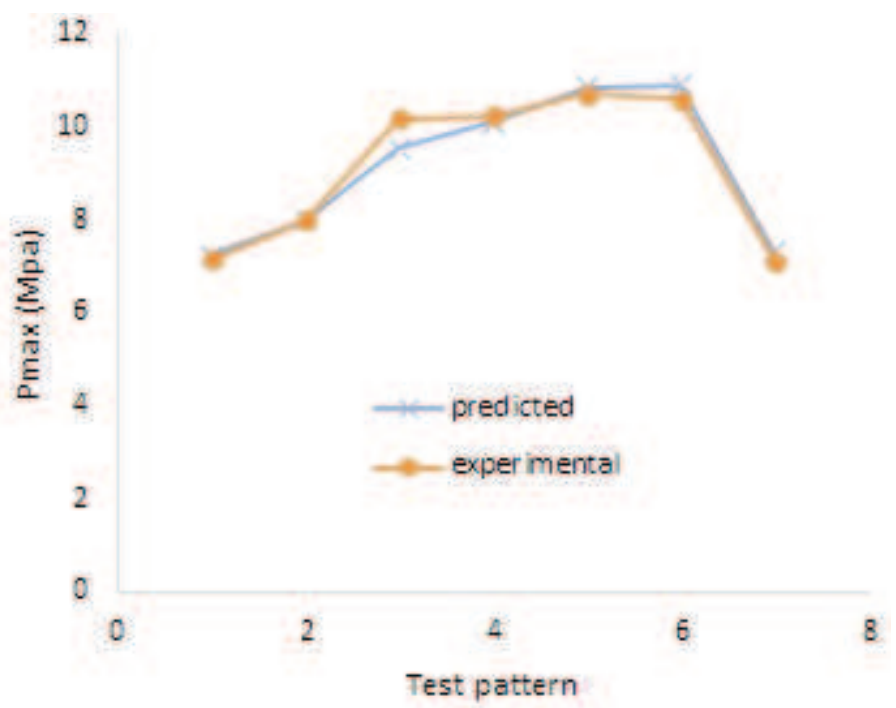

(e)

Figure 9: Comparisons of experimental results and the ANN predictions for (a) engine power, (b) Engine Torque, (c) BSFC (d) NOx (e) Pmax for various test patterns 
Table 4: Training and testing results

\begin{tabular}{lllllll}
\hline $\begin{array}{l}\text { Hidden layer } \\
\text { neurons }\end{array}$ & $\begin{array}{l}\text { Training } \\
\text { function }\end{array}$ & $\begin{array}{l}\text { Transfer } \\
\text { function }\end{array}$ & MSE & $R^{2}(A L L)$ & $\begin{array}{c}R^{2} \\
\text { (Training) }\end{array}$ & $\begin{array}{c}R^{2} \\
\text { (Testing) }\end{array}$ \\
\hline 6 & TRAINLM & LOGSIG & 0,001573 & 0,9671 & 0,9577 & 0,9911 \\
\hline 7 & TRAINLM & LOGSIG & 0,002476 & 0,9756 & 0,9734 & 0,9979 \\
\hline $\mathbf{9}$ & TRAINLM & LOGSIG & 0,006305 & 0,9844 & 0,9916 & 0,9892 \\
\hline 10 & TRAINLM & LOGSIG & 0,007409 & 0,9608 & 0,9970 & 0,7111 \\
\hline 15 & TRAINLM & LOGSIG & 0,00475 & 0,9178 & 0,9597 & 0,6370 \\
\hline 20 & TRAINLM & LOGSIG & 0,001802 & 0,9811 & 0,9779 & 0,9992 \\
\hline 6 & TRAINLM & LOGSIG & 0,001558 & 0,9807 & 0,9839 & 0,9805 \\
\hline 7 & TRAINGDX & LOGSIG & 0,063115 & 0,7065 & 0,7072 & 0,9248 \\
\hline 8 & TRAINGDX & LOGSIG & 0,035614 & 0,7165 & 0,7213 & 0,7210 \\
\hline 9 & TRAINGDX & LOGSIG & 0,085569 & 0,5191 & 0,5150 & 0,5332 \\
\hline 10 & TRAINGDX & LOGSIG & 0,033121 & 0,8399 & 0,8477 & 0,8600 \\
\hline 15 & TRAINGDX & LOGSIG & 0,010719 & 0,9554 & 0,9596 & 0,9724 \\
\hline 20 & TRAINGDX & LOGSIG & 0,043304 & 0,8050 & 0,7890 & 0,9426 \\
\hline
\end{tabular}

shows that the created ANN structure was successful. The correlation coefficient found around 0.98 also supports this claim.

\section{Conclusions}

The changes in performance, emission and ignition characteristics that occurred through the use of bioethanol-safflower biodiesel and diesel fuel blends in a diesel engine with a common rail fuel system were investigated in the present study. An ANN approach was applied by using the data obtained in the experimental studies. Torque, power, SFC, Pmax and NOx values in a diesel engine were tried to be predicted though ANN. ANN training was performed by randomly selecting the $70 \%$ of the data obtained in the experimental study. The remaining $30 \%$ was used for testing purposes. Values that were substantially close to the experimental values were predicted through the ANN application. In conclusion, it was seen that ANNs could be used for predicting performance and emission values in internal combustion engines. In this way, it would be possible to conduct time and cost efficient studies instead of long experimental ones.

\section{Acknowledgements}

This study was supported by the Selcuk University Scientific Research Projects Centre.

\section{References}

Acaroglu, M. and Aydogan, H. (2012). Biofuels energy sources and future of biofuels energy in Turkey. Biomass \& Bioenergy, 36:69-76.

Adeyemo O, Wise R, and Brent A, (2011). The impacts of biodiesel feedstock production systems in South
Africa: An application of a Partial Equilibrium Model to the Eastern Cape Social Accounting Matrix, Journal of Energy in Southern Africa, 22(1);1-11.

Agarwal, A.K. and Dhar, A. (2013). Experimental investigations of performance, emission and combustion characteristics of Karanja oil blends fuelled DICI engine. Renewable Energy, 52:283-291.

Amiri, S., Mehrnia, M.R., Barzegari, D., and Yazdani, A. (2011). An artificial neural network for prediction of gas holdup in bubble columns with oily solutions. Neural Computing and Applications, 20:487-494.

Armas, O., Martínez-Martínez, S., and Mata, C. (2011). Effect of an ethanol-biodiesel-diesel blend on a common rail injection system. Fuel Processing Technology, 92:2145-2153.

Aydogan, H., Altun, A.A., and Ozcelik, A.E. (2011). Performance Analysis of a Turbocharged Diesel Engine Using Biodiesel with Back Propagation Artificial Neural Network. Energy Education Science and Technology Part A., 28:459-468.

Aydogan, H., Ozcelik, A.E., and Acaroglu, M. (2011). The Effect of Peanut Oil Methyl Ester on the Performance and Emissions of a Diesel Engine with a Pump Injection Fuel System. Energy Education Science and Technology Part A, 28:189-200.

Balti, A., Sayadi, M., and Fnaiech F. (2013). Fingerprint Verification Based on Back Propagation Neural Network. Control Engineering and Applied Informatics, 15(3):53-60.

Breda, K. (2011). In $\square$ uence of biodiesel on engine combustion and emission characteristics. Applied Energy, 88:1803-1812.

Brunschwig, C., Moussavou, W., and Blin, J. (2012). Use of bioethanol for biodiesel production. Progress in Energy and Combustion Science, 38:283-301.

Canakci, M., Erdil, A., and Arcaklioglu, E. (2006). Performance and exhaust emissions of a biodiesel engine. Applied Energy, 83:594-605.

Cay, Y. (2013). Prediction of a gasoline engine perform- 
ance with artificial neural network. Fuel, 111:324331.

Demirbas, A. (2008). Biofuels sources, biofuel policy, biofuel economy and global biofuel projections. Energy Conversion and Management, 49:21062116.

Ma, Y., Zhu, M., and Zhang, D. (2013). The effect of a homogeneous combustion catalyst on exhaust emissions from a single cylinder diesel engine. Applied Energy, 102:556-562.

Fahd M.E.A., Wenming, Y., Lee, P.S., Chou, S.K., and Yap, C.R. (2013). Experimental investigation of the performance and emission characteristics of direct injection diesel engine by water emulsion diesel under varying engine load condition. Applied Energy, 102:1042-1049.

Ghazikhani, M., and Mirzaii, I. (2011). Soot emission prediction of a waste-gated turbo-charged DI diesel engine using artificial neural network. Neural Computing and Applications, 20:303-308.

Ghobadian, B., Rahimi, H., Nikbakht, A.M., Najafi, G., and Yusaf, T.F. (2009). Diesel engine performance and exhaust emission analysis using waste cooking biodiesel fuel with an artificial neural network. Renewable Energy, 34:976-982.

Guido, C., Beatrice. C., and Napolitano, P. (2013). Application of bioethanol/RME/diesel blend in a Euro5 automotive diesel engine: Potentiality of closed loop combustion control technology. Applied Energy, 102:13-23.

Hadi, R., Barat, G., Talal, Y., Gholamhasan, N., and Mahdi, K. (2009). Diesterol: an environment friendly IC engine fuel. Renewable Energy, 34:335-342.

Hafaifa, A., Djeddi, A.Z., and Daoudi A. (2013). Fault detection and isolation in industrial control valve based on artificial neural networks diagnosis. Control Engineering and Applied Informatics, 15(3):61-69.

Hazar, H. (2010). Cotton methyl ester usage in a diesel engine equipped with insulated combustion chamber. Applied Energy, 87:134-140.

Hsieh, W.D., Chen, R.H., Wu, T.L., and Lin, T.H. (2002). Engine performance and pollutant emission of an SI engine using ethanol-gasoline blended fuels. Atmospheric Environment, 36:403-410.

Hulwan, D.B., and Joshi, S.V. (2011). Performance, emission and combustion characteristic of a multicylinder DI diesel engine running on dieselethanol-biodiesel blends of high ethanol content. Applied Energy, 88:5042-5055.

Ioanaş, G.L. (2002). Modelling, Identification and Prediction of Inherent quasi-stationary Pressure Dynamics of a Common-Rail System using NeuroFuzzy Structures with Local Linear ARX models. Control Engineering and Applied Informatics, 14(3):61-70.

Ismaila, H.M., Nga, H.K., Quecka, C.W., and Ganb, S. (2012). Artificial neural networks modelling of engine-out responses for a light-duty diesel engine fuelled with biodiesel blends. Applied Energy, 92:769-777.

Park, S.H., and Lee, C.S. (2013). Combustion performance and emission reduction characteristics of auto- motive DME engine system. Progress in Energy and Combustion Science, 39:147-168.

Kannan, G.R., Karvembu, R., and Anand, R. (2011). Effect of metal based additive on performance emission and combustion characteristics of diesel engine fuelled with biodiesel. Applied Energy, 88:36943703.

Morisugi, H., Ohno, E. (1996). NOx Reduction Effects of the Policy to Reduce Diesel Automobiles and its Influence on Price Change. Transport, Land-Use and the Environment Transportation Research, Economics and Policy, 171-190.

Mrad, N., Varuvel, E.G., Tazerout, M., and Aloui, F. (2012). Effects of biofuel from fish oil industrial residue - Diesel blends in diesel engine. Energy, 44:955-963.

Park, S.H., Cha, J., and Lee, C.S. (2012). Impact of biodiesel in bioethanol blended diesel on the engine performance and emissions characteristics in compression ignition engine. Applied Energy, 99:334343.

Pilusa T.J., Huberts R., and Muzenda E. (2013). Emissions analysis from combustion of eco-fuel briquettes for domestic applications. Journal of Energy in Southern Africa, 24 (4): 30-36.

Qi, D.H., Chen, H., Geng, L.M., and Bian, Y.Z. (2011). Effect of diethyl ether and ethanol additives on the combustion and emission characteristics of biodieseldiesel blended fuel engine. Renewable Energy, 36:1252-1258.

SAE (2001). SAE handbook, MI Vol. 1, Warrendale, SAE: 1304-1306.

Sefriti, S., Boumhidi, J., Naoual, R., and Boumhidi, I. (2002). Adaptive Neural Network Sliding Mode Control for Electrically-Driven Robot Manipulators. Control Engineering and Applied Informatics, 14(4):27-32.

Sharkey, A.J.C., Chandroth, G.O., and Sharkey, N.E., (2000) A Multi-Net System for the Fault Diagnosis of a Diesel Engine. Neural Computing and Applications, 9:152-160.

Shi, X., Yu, Y., He, H., Shuai, S., Wang, J., and Li, R. (2005). Emission characteristics using methyl soyate-ethanol-diesel fuel blends on a diesel engine. Fuel, 84:1543-1549.

Singh, A.K., Tyagi, B., Kumar, V. (2013). Application of Neural Network based Control Strategies to Binary Distillation Column. Control Engineering and Applied Informatics, 15(4):47-57.

Soloiu, V., Duggan, M., Harp, S., Vlcek, B., and Williams, D. (2013). PFI (port fuel injection) of nbutanol and direct injection of biodiesel to attain LTC (low-temperature combustion) for low-emissions idling in a compression engine. Energy, 52:143-154.

Stone, R. (1999). Introduction to internal combustion engines. 3rd Ed. New York: Macmillan.

Torrisi, N.M., and Sabino, M. (2013). Biodiesel production control using PNN and Coriolis flowmeter. Neural Computing and Applications, 23:1275-1282.

Uzun, A. (2014). Air mass flow estimation of diesel engines using neural network. Fuel, 117:833-838.

Yilmaz, N., and Sanchez, T.M. (2012). Analysis of operating a diesel engine on biodiesel-ethanol and 
biodiesel-methanol blends. Energy, 46:126-129.

Yilmaz, S., and Bilgin, M.Z. (2013). Modelling and simulation of injection control system on a four-stroke type diesel engine development platform using artificial neural networks. Neural Computing and Applications, 22:1713-1725.

Zhou, J.H., Cheung, C.S., and Leung, C.W. (2013). Combustion, performance and emissions of ULSD, PME and B50 fuelled multi-cylinder diesel engine with naturally aspirated hydrogen. International Journal of Hydrogen Energy, 34: 14837-14848.

Zhu, L., Cheung, C.S., Zhang, W.G., and Huang, Z. (2010). Emissions characteristics of a diesel engine operating on biodiesel and biodiesel blended with ethanol and methanol. Science of the Total Environment, 408: 914-921.

Received 12 April 2014; revised 14 April 2015 